\title{
Underdogs, rebels, and heroes
}

\author{
Crime narratives as a resource for doing masculinity in \\ autobiographies
}

\begin{abstract}
This article shows how autobiographies of famous, socially well-established men (re)produce hegemonic masculinity through narratives of offending; how masculine performance is age graded; and that masculinity constructions are accomplished both via what is said and what is not said. The autobiographies of the footballer Zlatan Ibrahimović, the former high jumper Patrik Sjöberg and Sweden's most famous criminologist, Professor Leif G.W. Persson, are analysed. Common to all three is that they openly describe a variety of crimes they have committed. These three men are highly respected in Sweden and none of them is considered as "a criminal" in general opinion. This article shows that crime can be a resource for doing masculinity even for famous, successful and highly respected men. The crime narratives in these autobiographies tell us something about the culturally accepted representations of masculinity that may not just pass as possible, but even as desirable.
\end{abstract}

Keywords: hegemonic masculinity, autobiography, narrative analysis, violence, crime

DESPITE THE CONTEMPORARY focus on crime as a major problem (Tham 2018), we often see popular media representations of events that constitute criminal offences according to a legalistic interpretation, but which are not presented or perceived as crimes. This is the case in, for instance, television series, films, books - or autobiographies - in which heroes rebel against sluggish bureaucracies, engage in sensation seeking and risk taking, and exact revenge for various forms of injustice. Sometimes the hero is even explicitly criminal, and the audience is expected to sympathise with both the police and the individual being pursued. Most often these actions that "are" but are not presented as, crimes, are carried out by men. This link between crime and masculinity, which serves to normalise and mitigate the offences, is well established in the field of feminist-oriented criminology (Davies 2011). When boys or young men commit criminal offences, these acts are often regarded as "boyish pranks", in line with the expression "boys will be boys". ${ }^{1}$ This

1 This is not, however, the case for all boys or young men, or for all offences. Class, race/ethnicity and place are also of central significance (Davies 2011). 
normalisation of (young) men's offending serves to obfuscate both the offences and the link to masculinity. Even we - both criminologists with an interest in gender and crime - do not always see this link. When we first read the three autobiographies analysed in this article, we did not notice all the crimes depicted in the books. What stood out was the construction of hegemonic masculinity. Since this was so prominent, we did a close reading to find clear, concrete examples to use in our teaching. The close reading revealed the number of narratives about these men's own involvement in crimes, which we decided to analyse in more detail.

In this article we show how autobiographies of famous, socially well-established men (re)produce hegemonic masculinity through narratives of offending; how masculine performance is age graded; and that masculinity constructions are accomplished both via what is said and what is not said. Three autobiographies of famous, socially wellestablished men, who all may be viewed as symbolizing hegemonic masculinity, are analysed: the footballer Zlatan Ibrahimović, the former high jumper Patrik Sjöberg and Sweden's most famous criminologist, Professor Leif G.W. Persson. Although the selection of books is a coincidence, they have much in common. The three men are portrayed as having successfully climbed the social class ladder, and - according to their autobiographies - they have also all committed a considerable number of criminal offences. However, none of them is known for being, or is usually regarded as, an offender or criminal. How is it that the biographies of these successful men contain so many stories about their own criminality? We argue that the crime narratives provide opportunities for the authors to be portrayed as risk-takers, fearless, innovative, rebellious, strong and capable of violence - all markers of masculinity. The purpose of this article is to show how narratives of involvement in crime are - and are not - described, and how this may be related to acceptable forms of masculinity in the broader societal context.

\section{Theoretical framework}

Criminological research shows that crime may be used as a resource for doing masculinity (Messerschmidt 1997, 2018a). Violence, or being capable of violence, is particularly strongly linked to the performance of masculinity (Kimmel 1994; Kimmel and Mahler 2003; Kolnar 2005; Messerschmidt 2004). Having potential for violence is not deviant, but rather constitutes a central masculinity norm (Pascoe 2011; Berggren 2014). Nor is this a recent insight. As early as the 1960s, Matza and Sykes (1961) argued that toughness and aggressiveness were valued as markers of masculinity not only in gangs and criminal environments, but also in more conventional contexts.

Connell argued as early as three decades ago (1995) that in western culture, masculinity is defined by power and domination (see also Whitehead 2002; Connell \& Messerschmidt 2005; Segal 2007; Messerschmidt 2018b, 2019). Connell emphasized the relational nature of gender constructions and distinguished several forms of masculinity and femininity. She claimed that hegemonic masculinity is always constructed in relation to various subordinated masculinities and femininities. Thus, power relations are not only present between men and women but also between men (cf. Messersch- 
midt 1997, 2018b; Pettersson 2014). An effective way to do masculinity is making other men unmasculine. This may be done by presenting other men as cowards or feminine, and the use of homosexuality and allegations of being a "faggot" are common (Pascoe 2012; Kimmel 1994). In line with Messerschmidt (2018b, 2019) we argue that the concept of hegemonic masculinity remains fruitful to critical masculinity studies. As will be seen in our analysis an important element in the crime narratives in the autobiographies is domination over other men and masculinities.

The domination sometimes takes the form of demonstrating their own potential for violence in relation to other men. Kolnar (2005) discusses men's violence in terms of processes of exclusion and inclusion, and argues that violence may serve different functions depending on the context. Kolnar argues that violence is paradoxical in its character. He differs between the centripetal and the peripetal forms of violence, where peripetal is excluding and centripetal is including men in the broader society. We argue that other types of act that may be viewed as crimes may also serve to promote inclusion and exclusion. In the field of criminology, crime has often been studied in relation to exclusion (from mainstream society). This article instead directs its focus at the way crime may serve to promote inclusion. The autobiographical crime accounts ${ }^{2}$ that we analyse did not produce exclusion, in the form of expressions of disapproval of Ibrahimović, Sjöberg or Persson when the books were published.

We apply an intersectional narrative analysis, which involves examining how social positions and power dimensions, such as sex/gender, ethnicity/race, social class, age, et cetera, interact with one another (Messerschmidt 1993; Pascoe 2012; Spector-Mersel 2006; Berggren 2014). Spector-Mersel (2006), Carlsson (2013) and Bäcklin, Carlsson and Pettersson (2013) show how what is regarded as masculine at a certain age may appear unmasculine at another. Spector-Mersel (2006) argues that when research has attended to age, it has usually been analysed in inter-personal terms. However, ageing constitutes a central part of the way in which masculinity is constructed within a given individual. An individual's constructions of masculinity quite simply change with age, since masculinity norms are different for different age groups. Spector-Mersel (2006:71-72) argues that "hegemonic masculinities are tied to specific phases of the life course. The integration of this claim with the narrative metaphor sets the stage for the hegemonic masculinity scripts. These are cultural exemplary-plots that draw social clocks for masculinity, determining diverse contents of desired manhood at different points in a man's life". This article focuses on how crime is described at different ages, but in relation to the same individual. Ibrahimović (born 1981), Sjöberg (born 1965), and Persson (born 1945) are also of different ages compared to one another when their earlier lives are described from their present, contemporary position.

Our approach to the autobiographical texts is in part based on the framework for analysing life history narratives proposed by Järvinen (2004) who regards these as narratives about the past viewed from a constantly changing present. She discusses what is required

2 Narrative and account are used synonymously throughout the article. The term account is not used in the same sense as that in which Scott and Lyman (1968) use it. 
for a narrative to be accepted and argues that "the plot of our narratives has to be typical typical for the category of people we belong to, typical for our time, typical for the problems we struggle with. [...] By telling their stories in adequate ways, narrators demonstrate that they are worthy members of the group and that they know and share the group's ideals for respectable and coherent self presentations" (Järvinen 2004:54-55). Autobiographies may be read as culturally accepted narratives (Sandberg 2010; Oksanen 2012), and as such they have a great deal to tell us about doing masculinity, ethnicity/race, class, sexuality, and age in contemporary Sweden and other western contexts. We thus view these autobiographies as narratives about the past that proceed from, and are embedded in, a present. Our focus is directed at the representations of manliness and masculinity (Whitehead 2002:41-42) that are embedded in the narratives, and not what the narratives say about Ibrahimović, Sjöberg or Persson as individual men. Like Oksanen (2012:129-130), we would argue that "the key point is not whether the autobiographies are fact or fiction, but it is rather the representational level of discourses, myths and narratives that is important". Sandberg (2010) argues that too much attention has been focused on discussing whether or not narratives are true, and has advocated the view that "whether true or false, the multitude of stories people tell reflect, and help us understand, the complex nature of values, identities, cultures, and communities" (Sandberg 2010:448). In line with Oksanen and Sandberg we would argue that the narratives that were chosen (and not chosen) for inclusion in the autobiographies examined says something important about the cultural context in which they have been written. The point of departure is that the crime narratives both constitute representations of masculinity and - on the basis of the social positions from which they are described contribute to the reproduction of what can be perceived as acceptable masculinity.

One overarching narrative that appears in each of the autobiographies is the classic hero narrative, which exhibits many elements in common with Jon's (2007) concept of cowboy masculinity. The cowboy narrative is a hero story that includes several typical characteristics; the cowboy is fearless, physically strong, intelligent, smart and technically competent. He allies himself with the local population against a powerful oppressor. The cowboy cannot tolerate injustice and he struggles successfully against the system. Through this struggle, he forges ties to the local population, and to at least one woman, but despite this, the story ends with him leaving alone. "The hero is sufficient to himself! He is independent and autonomous, unaffected by others" (Jon 2007:32). The cowboy concept is referring to historical and mythological heroic ideals that exist in contemporary Western popular culture. These ideals served as important role models for the institutionalised boys Jon studied, and for the working class in general (Jon 2014:20-24). Another important aspect of cowboy masculinity is that it includes and emphasizes style - the way one wants to display and show off oneself. The boys in Jon's study thus adopted a "tough" style, inspired by heroic ideals, where they stretched the boundaries, sometimes through crime (Jon 2014:24). Jon's analysis is focused on what the boys choose to ascribe importance to as against what they protest against. Autobiographies may be viewed as texts that show precisely what the author chooses to ascribe importance to.

Järvinen (2004) has discussed storylines and the gender differences found in these, both in terms of how they are told and who is able to tell them. She argues that "[f]rom 
ancient times until today, manstories have been stories about achievement, while womenstories have been stories about social embeddedness" (ibid.:56-57). As an example, Järvinen specifically refers to the hero myth, arguing that "the story of a person who, dedicated to a quest, ventures forth from the everyday world, fights and defeats dangerous forces, returns home and is rewarded for his deed - is a clear-cut 'manstory"' (ibid.:56).

The intersection between class and gender emerges clearly in Jon's study, as is also the case in the three autobiographies examined in this article. The stories that are narrated in the three autobiographies are characterised by an emphasis on embeddedness in the working class, particularly during childhood and the years of youth, and also in the form of an ever-present working-class "heritage".

\section{Material and analysis}

The material consists of three autobiographies. Two are written by Swedish sportsmen who are or have been members of the international elite in their respective sports: Zlatan Ibrahimović ${ }^{3}$ and Patrik Sjöberg ${ }^{4}$. The third is written by one of Sweden's best-known professors Leif G.W. Persson. The fact that the biographies have received a great deal of attention and none of the authors is viewed as a "criminal" or "former criminal" constitutes a strength in relation to our research objective. We do not wish to examine whether crime may be used as a resource for doing masculinity among persons with clear links to crime, but rather the extent to which narratives about one's own offending may also be used as a resource for doing masculinity by famous, social well-established men. In this way, the autobiographies tell us more about general masculinity norms than would autobiographies written by individuals who define themselves, or are defined by others, as "criminal".

Järvinen (2004) writes that narratives are related to the environment that the presentations have been produced for. In this sense, autobiographies are of particular interest, since they may be assumed to have been produced for a more general group in society than other forms of life histories, such as research interviews. Further, they may be assumed to have been more carefully prepared than the life histories in interviews. The texts have been subject to a series of rewrites before the books' publication. They thus constitute a special form of life history because of the highly considered nature of the narrative process. The three biographies have indeed reached a large audience and are therefore particularly interesting to analyse.

The analysis is based on the books in their entirety, but we have conducted a close reading of all narratives that include descriptions of involvement in crime. We have then identified a number of themes, which also constitute the framework for the presentation of our analysis: 1) The potential for violence and physical strength, 2) Fearless, risk-taking and slightly mad, 3) Innovative, 4) Rebelling against the system, 5) Being responsible, and 6) Retaliation and revenge.

3 Co-authored with David Lagercrantz.

4 Co-authored with Markus Lutteman. 
Before we move on to the analysis, we must first touch upon an ethical aspect of our work. The fact that our analysis focuses specifically on accounts of involvement in crime, which are taken out of context, may serve to present Ibrahimović, Sjöberg or Persson in an unfavourable light. We would therefore like to emphasise that this has not been our intention. Our study is not of Ibrahimović, Sjöberg or Persson as individuals, but rather the representations that are produced by their narratives about involvement in crime, and what these representations tell us about masculinity norms in a much broader context.

\section{Analysis}

We would like to begin by noting that it is not only by means of narratives about crime that masculinity is constructed. It should be noted that in addition to the masculine characteristics that are portrayed in the crime accounts, other traits are also emphasised by means of other types of narratives - characteristics such as being active, heterosexual, successful, purposeful, having a high pain tolerance, and being intelligent. All three men are also described as being leaders, individualists, vengeful, smart, and courageous winners - rebels, who have the courage to play for high stakes, to swim against the tide and to resist rules and authorities. All three autobiographies may be characterised as hero stories. Ibrahimović, Sjöberg, and Persson are all described as working-class boys who grew up in difficult circumstances and sometimes spent time in dubious company, who engaged in "boyish pranks" and sometimes serious offences. Thanks to their talent, and hard and focused work, they pulled themselves up, earned large sums of money and became rich and famous. Along the way, they all suffered various types of setbacks, which they usually succeeded in emerging from as victors. In this sense, they are all typical "manstories" (Järvinen 2004), but all three also contain several narratives that provide some nuance to accepted masculinity constructions, by describing ambivalence, grief, vulnerability, pain and anxiety. The majority of these narratives do not, however, appear in connection with accounts of the authors' involvement in crime, and for this reason most of them fall beyond the scope of our analysis. Another aspect which is conspicuous by its absence in the analysis below is ethnicity. It is absent in Sjöberg's and Persson's books, which may be associated with the tendency for the norm to often remain invisible. In Ibrahimović's autobiography, however, ethnicity is manifested clearly, although not in the accounts of crime, and is therefore not part of our analysis.

\section{Crime narratives as a resource for doing masculinity}

Before we present our analysis of the crime narratives in more detail, it may be of interest to show how many accounts of criminal behaviour are found in the autobiographies examined. The narratives have been coded on the basis of a legalistic interpretation, based on the offences described in the accounts, as defined in Swedish law. ${ }^{5}$ It is not our intention to argue that Sjöberg, Persson and Ibrahimović have committed large

5 A few of the events/offences are described more than once in the autobiographies, which means that the same incident may appear more than once in Table 1. 
numbers of offences - most people commit some offences, particularly in their youth. Of interest is the fact that they have chosen to narrate these events, which (on the basis of our interpretation, but perhaps not their own) may be viewed as criminal offences, and how these accounts are (not) narrated.

Table 1: Accounts of involvement in crime.

\begin{tabular}{|c|c|c|c|}
\hline Offence & Ibrahimović & Persson & Sjöberg \\
\hline Alcohol and cigarette smuggling & & 2 & \\
\hline Assault & 11 & & 3 \\
\hline Breach of postal or telecommunications confidentiality & 1 & & \\
\hline Breach of professional confidentiality & & 1 & \\
\hline Causing bodily injury or illness & 1 & & \\
\hline Criminal damage & 6 & & 1 \\
\hline Destruction causing public endangerment & 2 & & \\
\hline Driving through a red light & 1 & & \\
\hline Driving without a license & & & 2 \\
\hline Drug offences & & $4+^{*}$ & 15 \\
\hline Environmental offences (complicity, but not presented as such) & & 2 & \\
\hline Fishing offences & & 1 & \\
\hline Fraud & & & 2 \\
\hline Harassment & & & 1 \\
\hline Hunting offences & & 2 & \\
\hline Impersonating a public officer & 1 & & \\
\hline Non-sexual molestation & 1 & & \\
\hline Offences against National Service legislation & & 1 & \\
\hline Parking offences & & & $5+$ \\
\hline Preparation to commit murder & & 1 & \\
\hline Receiving stolen goods & & & $2+$ \\
\hline Speeding offences & 5 & 4 & $4+$ \\
\hline Tax offences & & 3 & 12 \\
\hline Theft/petty theft & $11+$ & & $5+$ \\
\hline Unlawful possession of a weapon & 2 & 1 & \\
\hline Unlawful handling of a corpse/disturbance of a grave & & & 1 \\
\hline Unlawful threat & 4 & 1 & 1 \\
\hline Number of accounts of involvement in crime & 46 & 23 & 54 \\
\hline
\end{tabular}

* This figure relates to the number of concrete offences described. The plus sign indicates that the author makes it clear to the reader that the offence has been committed on a greater number of occasions than those for which a concrete account is presented. 
Table 1 shows both similarities and differences. The only offences that all three men are described as having committed are the unlawful threat offence and exceeding the speed limit. Given that research on masculinity has emphasised violence as a particularly central element in constructions of masculinity (Kimmel 1994; Kimmel \& Mahler 2003; Messerschmidt 2004), one might perhaps expect to find a greater number of accounts relating to violence. On the other hand, it is first and foremost the potential for violence that constitutes the central factor, namely the importance of appearing to be capable of violence, and this is presented in the autobiographies in other ways than via accounts of actually committing acts of violence. Not needing to fight may be viewed as being even more desirable, provided that one can fight if necessary.

Although the table might suggest that the autobiographies contain accounts of many offences, it is important to note that these accounts do not constitute central narratives in any of the biographies. All three men are primarily presented as lawabiding citizens who live honest lives, at the same time as they - sometimes in one and the same sentence - also are described as having crossed (and to some extent as still crossing) the line (of the law). Speaking of crime in the same breath as presenting oneself as a law-abiding individual may be interpreted as indicating a desire to present oneself as an honest person. Since the offences are described in other parts of the book, it might appear self-contradictory if these were not then also mentioned when the authors described themselves as being law-abiding or honest individuals. It may also be interpreted as indicating that it is important to present oneself as a person who has the courage to cross the line (of the law) and take the consequences.

Ibrahimović is presented as a person who would have become a criminal, if he had not become a footballer (Ibrahimović 2013:26). This illustrates the point made by Järvinen (2004) that life histories are presented from the perspective of the present. Ibrahimović is not presented as being criminal today, and on the basis of this position is not described as having been criminal then, despite the many offences that are described in his book. Describing offences committed in one's youth, which one is now looking back on as an adult, and from a well-established position, may also be viewed in the light of the social clock concept discussed by Spector-Mersel (2006). Following on from this introductory presentation, we will now move on to present the analysis based on the themes we have identified.

\section{The potential for violence and physical strength}

Ibrahimović is the one who is presented as possessing the biggest potential for violence and differs from Persson and Sjöberg in the way his physical strength, fearlessness and high pain tolerance are highlighted. A more bodily masculinity is constructed through the depictions of football as a violent, physically demanding sport with lots of body contact. His autobiography includes recurrent accounts of head-butting and other acts of violence committed during football matches. These may not be viewed as criminal offences in the legal sense, but in some of these accounts the violence takes place directly prior to or after matches or training sessions and has therefore been coded as involving assaults in the above table. These accounts demonstrate Ibrahimović's 
potential for violence, and at the same time his opponents are often presented as unmasculine (as cowardly and frightened). Presenting other men as being unmanly is a common strategy for making oneself masculine (Pascoe 2012; Messerschmidt 2019). One passage describes how a teammate (Zebina) played aggressively during training sessions, and how on one occasion he subjected Ibrahimović to a particularly brutal tackle.

I went up to him, right in his face: "If you wanna play dirty, say so beforehand, and I'll play dirty too!"

Then he headbutted me - bang! just like that - and things happened fast after that. I didn't have time to think. It was a sheer reflex. I hit out at him, and it happened right away. He hadn't even finished headbutting me. I must have hit him hard. He dropped down on to the grass [...] (Ibrahimović 2013:160)

The incident causes a stir in the entire team, but Ibrahimović receives the support of another player, who signals that Ibrahimovićs actions had been entirely correct. Another player, however, (Thuram) expresses his disapproval, and while he is telling Ibrahimović that he is "young and stupid" and that you cannot do what he has just done, he is interrupted by the coach, who yells at Thuram:

"Shut your mouth and get out of there." Of course, Thuram made himself scarce, he was like a little kid, and I left as well. I had to cool down.

Two hours later, I saw a guy in the massage room who was pressing some ice against his face. It was Zebina. I must have hit him hard. He was still in pain. He would have a black eye for a long time [...] (Ibrahimović 2013:161)

Note the connection between age and expected behaviour in the depiction of Zlatan as "young and stupid" (cf. Spector-Mersel 2006). Zlatan's description of Thuram as "a little kid" positions Thuram as unmanly, and Ibrahimović is presented as being physically the stronger in relation to Zebina (cf. Messerschmidt 2019). One recurrent theme in Ibrahimović's autobiography is the way in which he has more or less unconsciously hit someone really hard. It is also made clear in the above narrative that the coach approves of the violence, and in this sense, it may be said to serve an inclusive function for Ibrahimović (Kolnar 2005).

In several accounts relating to the footballing context, Ibrahimović appears not only as possessing a potential for violence, but as being almost uncontrollably physically powerful:

At one training session I picked him [the coach] up and hugged him out of sheer joy. I cracked two of his ribs. He could hardly walk [...] (Ibrahimović 2013:113)

Even when giving someone a well-meaning hug, the ribs of the person on the receiving end of Ibrahimovićs friendly gestures may get cracked. 
In contrast to Ibrahimović, in Persson's autobiography, accounts of violence are conspicuous by their absence although it is nonetheless Persson who describes perhaps the most serious violent offence found in the material, in the form of preparation for murder. Persson's mother had outwitted him, pried into a private, locked box and taken the money he had earned from illicit smuggling activities, which he describes in the book, and Persson plans to kill her by "finding some suitable poison with which to add a little spice to my mother's medication” (Persson 2011:172). He begins:

to experiment with nicotine, extracting the deadly poison from ordinary cigars, tasteless, odourless, difficult to trace, lethal, and in a way that fits well with my mother's medical history and her failing heart. I finally collect enough nicotine in crystalline form to kill a whole horde of mothers who have betrayed their sons. Then I let go of the whole idea, and the person who saves my mother's life is actually my little sister. She is ten years old, more impossible than ever, and who would take care of her if mum were to die? [...] Mum gets to live, and to avoid unnecessary temptation [...] I flush my lethal poison down the toilet. (Persson 2011:172-173)

What is interesting in this account is the way in which it is narrated. Something that may be described as a planned murder attempt is related almost in the form of an amusing anecdote. While it is true that the account shows Persson planning carefully and weighing the advantages and disadvantages, the potential for violence that is actually described in the above quote almost fades into the background.

As with Persson, accounts of violence are uncommon in Sjöberg's autobiography. He expressly distances himself from violence, but there are several accounts when he describes having used violence himself.

There is actually only one person whom I have consciously struck several times. That is Viljo [then Sjöberg's coach]. I was nineteen years old when it happened the first time. (Sjöberg \& Lutteman 2011:101)

The accounts of violence that do appear do so in a very special context, since this coach had subjected Sjöberg to repeated sexual abuse over a period of many years. ${ }^{6}$ As with Ibrahimović, the opponent, the one who gets hit, is described as unmanly, cowardly and afraid, but in Sjöberg's case, the accounts also present ambivalence, precisely because the coach is described as being so small and afraid. At the same time, the image of Sjöberg as non-violent is also constructed via these accounts of the use of

6 Sjöberg's book is written from the position of the victim of sexual abuse at the hands of his now deceased coach. This is what the title of the book - "What you didn't see" - is referring to, and it was this that was the focus for the marketing of the book, and that then became the focus of attention when it was published. The accounts of abuse are fewer however than the accounts relating to Sjöberg's involvement in crime. 
violence. They constitute an exception and are due to special circumstances (given the coach's offences against Sjöberg), and at the same time Sjöberg also expresses a sense of ambivalence in relation to his own violence.

As I drove along the streets, I was filled with conflicted feelings. In a way it felt good to slap him. It was a sense of liberation. At the same time, it felt like I had beaten a child. Because in a certain sense, Viljo was a child in an adult man's body. The next day I told him how close it had been that I had assaulted him seriously. "You, if anyone, know how hard I could have kicked you. You wouldn't have been able to stand up after that. If you behave like that one more time, you can't expect me to control myself." Viljo crouched and almost started to cry again. (Sjöberg \& Lutteman 2011:101)

After beating Viljo on a few occasions Sjöberg only needed to threaten Viljo in order to make him do what Sjöberg wanted. The potential for violence was established, but it is not something Sjöberg describes being proud of (Sjöberg \& Lutteman 2011:102). In this way, the violence in this context may also function to show that Sjöberg has a potential for violence - in certain, special circumstances he is able to fight - at the same time as the image of himself as a person who is against violence can be maintained as a central narrative.

The accounts of violence (apart from the example of the broken ribs) illustrate the importance of striking back at someone who has disdained you. All three men are depicted as having been treated unfairly and are at risk of being seen as inferior if they do not defend themselves. They all strike from a victim position (albeit very different ones) - Ibrahimović is head-butted and shown no respect, Persson's mother shows no respect for his personal belongings and Sjöberg has been subjected to sexual abuse. The narratives of violence can thus be understood as depictions of taking the power back when challenged.

\section{Fearless, risk taking and slightly mad}

All the books use accounts of crime as a resource for presenting fearlessness and risk taking (cf. Jon 2007), not least accounts of motoring offences in the form of speeding. On one occasion, for example, Ibrahimović is described speeding away from the police at $325 \mathrm{~km} / \mathrm{h}$. Ibrahimović is also proudly described as a sensation-seeking, courageous and uncommonly skilful driver. A male acquaintance who have been with him at the time of his speeding offences have been frightened by his excesses (Ibrahimović 2013:216) - a telling example of subordination of other masculinities (Connell 1995; Messerschmidt 2019). Part of the explanation for Ibrahimovićs driving excesses is ascribed to the sports cars he can now afford to buy. In Sjöberg's book it is noted that:

it is dangerous to have that kind of car when you are twenty years of age. [...] The speedometer went up to 300 , and I once pushed it the whole way. I didn't even think of the possible consequences of that kind of speed. (Sjöberg \& Lutteman 2011:115) 
Here we can relate to Spector-Mersel's (2006) discussion of masculinities that are appropriate for a certain age. In some places in the book, Sjöberg speaks from the position of a mature, responsible, adult man when looking back at the offences he says he has committed. He did not think about the possible consequences then, but he does now. These may be read as counter-narratives since they have a different connotation than most of the other crime narratives.

Of the autobiographies examined, it is Ibrahimović whose crime accounts present him as the greatest sensation seeker and risk taker, which may also be viewed in light of the fact that he is the youngest of the three men. It is not only by means of speeding and theft that Ibrahimović has got his kicks. At the time he became a professional footballer at the Ajax club, he spent some time in Malmö, in Sweden, and describes himself as having done "all sorts of stupid stuff" (Ibrahimović 2013:99). He and some friends:

went round with airbombs and stuff - illegal fireworks that we'd chuck into people's gardens. We did all kinds of crazy stuff to get our adrenaline going. [...] There was loads of racing round in cars, because that's how I function. If nothing's going on with football, I've got to get my kicks somewhere else. I need action, I need speed, and I wasn't looking after myself. (Ibrahimović 2013:99)

These fireworks are described at several places in the book. Ibrahimović and his friends bought them from a "geezer who made them illegally at home" (Ibrahimović 2013:120). Among other things, there are detailed descriptions how they placed one of these "airbombs" in a friend's workplace letterbox, which "exploded" into "seven million pieces" (Ibrahimović 2013:120). These events are described as "laddish pranks, the sort of things I've always needed and, in fact, the sort of things that still happens" although "my time in Ajax was my most out-of-control phase" (Ibrahimović 2013:120).

It is of interest to read the above examples on the basis of how these incidents are not narrated. There are no descriptions of thinking about possible disastrous consequences that these actions could have resulted in. The descriptions are not of petty offences, but they are nonetheless described as "boys fooling around" and they are presented as being fun, crazy and not particularly dangerous. This is in line with the generally accepted norm that "boys will be boys", and how this is used to excuse crime and violence (Davies 2011). Whether Ibrahimović still engages in this form of activity is not mentioned. However, the book makes it clear that he still would not shy away from committing offences in order to experience excitement, for example, even as a multi-millionaire he takes the opportunity, when it arises, to steal a whole trolley of IKEA furniture. The incident is not depicted as a crime, though. The trolley "happened to go past the checkout" and Ibrahimović's friend "was a smart guy" to push, as did Ibrahimović.

So we ended up getting a load of the stuff for free, and of course we enjoyed that. Don't think it was about money, though. It was the buzz. It was the adrenaline. It was like when we were kids in the department store. (Ibrahimović 2013:121) 
This narrative is in line with cowboy masculinity and illuminates the intersection between class, age and gender. By clearly stating that it is not about the money, Ibrahimović is portrayed as a successful man. The reference to childhood displays Ibrahimović as still being youthful, tough, and cool - not a boring adult, playing by the rules. He can still cross the line when opportunity is given (cf. Spector-Mersel 2006). The reference to childhood also points to Ibrahimovićs working-class background. Although it is the kicks that Ibrahimović nostalgically remembers, there were also other reasons to steal as a young man.

\section{Innovative}

In the context of this theme, we see the emergence of the significance of social class, particularly in Sjöberg's and Ibrahimovićs autobiographies. If you lack the resources to obtain things in legitimate ways, you acquire them by other means. As early as the 1930s, Merton (1938) described how conflicts between goals and means can lead to experiences of strain. If you lack legitimate means to achieve economic success, one strategy is to instead turn to illegitimate means. Both Ibrahimović and Sjöberg describe experiences of strain. Ibrahimović, for example, is described as a "pauper" at several places in his book. Starting his upper secondary education at a school where the students came from the more elegant parts of town was a shock:

At Borgarskolan, kids had Ralph Lauren sweaters, Timberland boots and shirts with collars. Imagine! I'd hardly ever seen a guy wearing a button-front shirt with a collar before, and I realized immediately that I needed to take drastic action. There were loads of fit girls in school. It wouldn't do to go and chat them up while looking like a guy from a council estate. (Ibrahimović 2013:41)

Here we can see how the significance of class interacts with the significance of gender, heterosexuality and place (cf. Hammarén 2008). Awareness is expressed of what passes as acceptable masculinity in Ibrahimovićs home context (a less privileged suburb) has little status in this new context - in this instance in relation to girls. One of a number of solutions to this situation was to steal.

I needed some cool stuff. Otherwise, I'd have no chance in the schoolyard. So I pinched one guy's music player, a wicked MiniDisc. (Ibrahimović 2013:42)

In another passage, in a footballing context, Ibrahimović is described as rebelling against the prevalent middle-class norms by exaggerating his poverty and suburban identity by pretending to have no money at all (Ibrahimović 2013:35-36) but in the school context, in relation to all the "fit girls", he does not do this. This also shows that the significances of class and place may carry more weight than that of gender. The quotation above manifests the feeling of a sense of inferiority in relation to the girls at school.

Sjöberg's autobiography also describes both himself and his family as having expe- 
rienced economic hardship. In his youth he bought a great deal of stolen goods, since he would never have been able to buy these things in shops (Sjöberg \& Lutteman 2011:29). In one crime account, which is focused on thieving, and which shows how smart and innovative Sjöberg and his friends were, Sjöberg describes how when they were young they sold newspapers. Although the story begins by describing how Sjöberg and his friends were engaged in honest work, the narrative is mostly focused on how they swindled their employer (and others) out of the profits (Sjöberg \& Lutteman 2011:30). Persson's (2011:154) autobiography also presents him as being innovative, not least in connection with an account of how he sold smuggled alcohol and tobacco, for example, and here too the intersections with both class and age emerge clearly.

\section{Rebelling against rules and authority}

One central element in Jon's (2007) concept of cowboy masculinity is the rebel who revolts against an unjust system. It is first and foremost in Sjöberg's book that crime accounts are employed as a resource to construct rebelliousness. The narratives are often focused on how Sjöberg rebelled against the way that athletes were at that time required to have amateur status, in order to be allowed to participate at the Olympics, and thus were precluded from earning money from their sport. The crimes described in Sjöberg's autobiography often take the form of tax offences, but also include conning the system in other ways. Since athletes were unable to use their sport as a paying occupation, their money had to be held in trust at the Swedish Athletics Association. "It was like living under guardians. The system naturally encouraged cheating" (Sjöberg \& Lutteman 2011:151), for instance in the form of faking travel expenses forms, exaggerated expenses claims or invented costs based on fake receipts. In his description of how he cheats an unjust system, Sjöberg also provides examples of his own smartness - a recurrent theme in his autobiography.

It was the first time that I had lost my license. After that I was more careful about losing it. Not by reducing my speed, but by joining the Association to Abolish the Speed Limit [Föreningen för fri fart, FFF]. Every month, FFF sent out a list of all the unmarked police cars in the country, and which counties they were in. In addition, of course, I had a police radar detector and a police radio in the Porsche. (Sjöberg \& Lutteman 2011:114-115)

Accounts of motoring offences can also provide opportunities to describe rebellion against the law enforcement in other ways - as one man against the system. On another occasion (Sjöberg \& Lutteman 2011:240), when Sjöberg had once again been caught speeding, he was given two days to surrender his driving license (individuals are sometimes allowed to drive to their destination before their driving license must be surrendered), which he then ignored. Taking his car, and being in a hurry, he drove in excess of the speed limit, and was stopped once again, this time by "a particularly zealous traffic officer" who pointed out that Sjöberg was driving much too fast. "The only appropriate thing to do was of course to deny this," writes Sjöberg, which then 
leads to an account of power games between Sjöberg and the police officer. The police officer informs Sjöberg that he will be called to attend a trial. Sjöberg responds that he knows his rights as a non-resident Swede, he has the right to appoint a representative, and he will appoint the police officer!

I knew that he did not have the right to refuse this assignment. In addition, he would not get paid for it, because it would be done outside of working hours. But he was not aware of all this. [...]

"You mean that I have to go to court and say that you deny the offence?" [the officer says]

"Yes, that's what you do."

"That can't be right."

He went off and made a phone call, and then came back looking very sour.

“I mean, for fuck's sake. What a bloody system.” (Sjöberg \& Lutteman 2011:240241)

In this crime account, Sjöberg succeeds in cleverly duping the representative of law and order by turning the system against him. Sjöberg is so smart that he knows the system better than the police officer himself! Not only is he a rebel, he is also portrayed as a hero who brilliantly overcomes the slow and wicked "sheriff". The similarities with Jon's (2007) cowboy masculinity are striking. It is also interesting to note that Sjöberg describes denying the offence as being the only natural course of action in this situation. Here we can relate this to what is not said in this account. There are many other, considerably more effective, options than denial, if the intention is to disengage oneself from a situation involving the police as smoothly as possible. A polite apology and showing that one accepts responsibility for what one has done can often constitute a more successful strategy for achieving this end (Pettersson 2012), if the objective is to get off as lightly as possible. If the objective is instead to rebel against the law enforcement, denial is a more effective strategy.

Persson's autobiography also includes examples of rebellious accounts of crime:

As early as the first day that I'm sitting there in my sentry box, I once again end up on the path to crime, not because of alcohol and cigarettes this time, but rather in a much more morally dubious combination of environmental crime and financial irregularities. [...] If future archaeologists were to come up with the idea of excavating the beautiful, wooded hill that lies beside the E4 slip road, just north of the gates to Haga Palace, then they might want to think of me. A good deal of all the rusty fridges and other crap that is lying there leaking Freon and heavy metals is a memorial to me and my summer at Haga. (Persson 2011:158-159)

What is interesting about this quotation is the way in which Persson presents himself as being the reason why these environmental offences were committed. While he was certainly complicit, it can be seen from earlier passages in the book that it was first 
and foremost a question of lorry drivers paying Persson to look the other way, without giving him much of a chance to object, when they arrive at the fly tip and dump the environmentally hazardous waste. This account is also interesting to analyse on the basis of how it is not narrated. An alternative narrative might have described a fear about saying no to older lorry drivers, or shame at having been complicit in these offences. Instead Persson chooses to present himself has being more responsible than he needs to. The way in which the account of these offences is presented is in itself rebellious - instead of being an account about a young man (Persson was 18 at the time) who did not have the courage to say no to older lorry drivers. Another crime narrative that may be interpreted as rebellious is found in Persson's account of the drug offences he has committed over the course of his life. He writes that he has never abused drugs, but says that he has tested most things "from heroin and cocaine all the way down to cannabis and Indian hemp, during my years as a crime researcher" (Persson 2011:339). By stating that:

irrespective of what I have swallowed, inhaled or even injected into my veins, it has never led to my feeling any craving, not even a temporary desire to continue, to at least try one more time. (Persson 2011:339)

Persson presents himself as a person who is in control. The reason that he "as an adult has tested different narcotic substances" is his "work as a crime researcher" (Persson 2011:339).

A desire to know what I am talking about on the basis of my own experience, and not just what I have learned by reading about it or from what others have told me. Anything else would have been negligent, almost official misconduct for a person like myself. (Persson 2011:339)

On the basis of his position as a researcher, Persson makes the commission of a large number of drug offences appear both rebellious and responsible.

\section{Responsible}

One theme that, for us unexpectedly, emerged from the analysis was that of crime accounts that function as a means of portraying the authors as being responsible. Such accounts are not common, but they do occur, first and foremost in Sjöberg's book, while there are also examples in Ibrahimovićs autobiography, where by presenting himself as previously having been irresponsible, he is by extension described as being a (more) responsible man now. In this sense Ibrahimović is portrayed in line with the hegemonic masculinity script of young boys - boys will be boys as an excuse for crime - and the script of older more responsible men (cf. Spector-Mersel 2006; Davies 2011).

Sjöberg's autobiography includes several examples of how crime accounts may be used to portray him as a responsible person. One such account describes how a young Sjöberg, together with a large group of other students, engaged in extensive vandalism 
at school. When the school principal called all of the secondary school classes to an assembly in the gym hall, and encouraged those who had the courage to do so to admit to what they had done, the room remained completely silent.

\begin{abstract}
I looked at my co-criminals, but nobody appeared to be making any effort to stand up. So I stood up myself and went and sat between the goalposts. [...] Then nothing happened for a long time. I sat there by myself, and none of the other "hooligans" stood up. In the end I looked at some of them and said: "Oh come on! Am I the only one who's done all this?" Slowly one of the other guys stood up and slouched over to me. Then one more, and then another. In the end there were almost twenty of us packed into the handball goal. (Sjöberg \& Lutteman 2011:12-13)
\end{abstract}

Sjöberg is presented as a leader with backbone, who takes responsibility for what he has done and who also encourages that the others take responsibility for their actions. Another way in which Sjöberg is portrayed as responsible in relation to crime is illustrated in an account of the events linked to him and a number of other people being arrested for cocaine use in connection with the Athletics World Championship in Gothenburg. In connection with this incident, Sjöberg describes how he immediately confessed and admitted responsibility when he was arrested by the police. He also took responsibility for his actions in a press release (which is published in full in his autobiography) and apologised to the active athletes who had been linked to the incident, despite themselves being completely innocent, and explained that they had nothing to do with what had happened. Another element to this story is found in the fact that another former sportsman was also arrested, Sven Nylander, who continued to protest his innocence for a long time. Nylander also suggested for a long time that it could have been Sjöberg who had caused him to consume the drugs he had taken without his own knowledge. By describing Nylander (who much later did in fact confess to having consciously taken the cocaine) as irresponsible and shocked by the incident, and as having been confused and unresponsive at the police station, Sjöberg is made to appear even more responsible. These two narratives allow Sjöberg to be portrayed as a better, more straightforward person in relation to the other boys/men, who then appear as cowards (cf. Kimmel 1994; Pascoe 2012; Messerschmidt 2018b, 2019).

\title{
Retaliation and revenge
}

This theme is central in all autobiographies. It emerges in part in accounts of the authors' childhood and teenage years, when adults have stigmatised them as lower status working class, "social cases", troublemakers or black sheep, but also in accounts of how they have been mistreated as adults, not least by journalists. The autobiographies can themselves be viewed as manifestations of retaliation, with the authors' own interpretations now having precedence. The desire for retaliation and revenge that is expressed in the autobiographies may be understood in light of one mark of masculinity, namely the view that real men hit back and exact revenge. Some of the crime accounts also 
include a clear revenge motive. Persson's plans to murder his mother are the result of her having outwitted and betrayed him by taking the money he had earned from smuggling offences. Several of the accounts described by Ibrahimović that relate to violence also include motives of revenge. Among other things, Ibrahimović describes bossing around at a meeting with the journalists at a tabloid newspaper that had repeatedly written unfavourable and offensive headlines about him:

and I think I scared them out of their wits, to be honest. I even chucked a bottle of water at their heads. "If you were from my 'hood, you wouldn't have survived", I said, and maybe that was harsh. (Ibrahimović 2013:168)

In this account, Ibrahimović plays on the media image of the "dangerous hood" in which he grew up together with (other) immigrant boys, and employs this as a resource to instil respect and create fear by using attitudes and action to perform a "hood masculinity" that radiates a sense of dangerousness (Hammarén 2008). ${ }^{7}$

\section{Concluding discussion}

Our objective has been to show that (certain types of) crime narratives, how they are narrated and not narrated, can constitute a resource for doing masculinity, and may thereby serve an inclusive function. As noted in the introduction, popular media is full of manly heroes carrying out acts that constitute criminal offences according to a legalistic interpretation, but which are not presented or perceived as crimes. This link between crime and masculinity, which serves to normalise and mitigate the offences, can also be seen when boys or young men commit criminal offences, and their acts are regarded as "boyish pranks", in line with the expression "boys will be boys" (Davies 2011). It is against this backdrop that the accounts presented by Persson, Ibrahimović and Sjöberg of their own involvement in crime should be viewed and understood. In line with Kolnar (2005) we show how the paradoxical nature of crime narratives emerges in the distinction between the peripetal and the centripetal forms of crime. The distinction refers to the different motions that narratives of crime can take. Peripetal crime accounts marginalize the individual or drive him out into the periphery of a social field (exclusion). Centripetal crime narratives legitimize the individual and drive him towards a centre (inclusion). What characterizes the centripetal crime narrative and what determines if the narrative will serve an inclusive or an excluding function? Based on our analysis we believe several factors are of importance. One aspect seems to be the obfuscation of the crime itself which is dependent on 1) who is described as engaging in the actions concerned, 2) the time and place at which they are described

7 Ibrahimović is not an immigrant. He was born in Sweden to immigrant parents, although the book cover actually presents him as an immigrant. Hammarén (2008) shows that coming from a less privileged neighbourhood, where the proportion of immigrants is high, boys and men are often perceived as "dangerous immigrants", regardless of their actual background. 
as occurring, 3) against and for whom they are described as being directed and as having consequences, and not least 4) whom the account is narrated by and on the basis of which position. In other words, narratives of certain types of crime (like theft, assaulting other men, tax offences, criminal damage, alcohol and cigarette smuggling, drug offences, et cetera), and not others (for example assaulting or raping women or children), narrated in specific ways - highlighting courage, strength, smartness, rebelliousness, et cetera - and not others (for example shame, vulnerability, fear, weakness cowardice, lacking self-control, et cetera), narrated from a socially well-established, famous position (like Sjöberg's, Persson's and Ibrahimović's) serves an inclusive function and obfuscates the crimes. The fact that Persson, Ibrahimović and Sjöberg are all successful, well-established men is of significance. If Ibrahimović "had become a criminal" instead of a professional footballer, the crime accounts presented in his book would appear in a very different light - they would appear as the beginning of a young "immigrant boy's" criminal career.

There is nothing new to show that courage, individuality, strength, potential for violence, risk-taking, intelligence, et cetera, are important markers of masculinity. Our contribution is to show that famous, socially established men - not known for having a criminal history - can present themselves as having these qualities by writing about their own involvement in crime - without framing their actions as crimes (aside from Persson's statement that he would have served several years in prison for smuggling if it had been reported to the police, or Sjöberg's explicit accounts of tax, speeding, and drug offences). Illegal actions are mostly framed as tough, cool, smart, dangerous, fun, and even responsible accomplishments. When we, as researchers, are counting accounts of actions and label these in legalistic terms as for example preparation to commit murder, destruction causing public endangerment, assault, et cetera, we are making an analytical point. By revealing the crimes, we believe we are illuminating the paradoxical nature of hegemonic masculinity norms. To break norms is the norm, especially for the (working-class) man. For how can an underdog become a hero if norms/laws are not broken? The cowboy story tells that norms/laws are there to keep the underdog in place. Playing by the rules will not lead to success (cf. Jon 2007, 2014). The intersection between class and gender is striking. A real (working-class) man ought to have experiences of rebellion, courage, strength, violence, taking risks, and so on. If these experiences are gained by (presenting) your own involvement in (certain types of) crimes, it does not affect the construction of masculinity in a negative way. On the contrary.

Another contribution is the focus on what is not being said. As pointed out in the analysis the crime narratives might have been narrated in quite different ways, describing fear, weakness, vulnerability and ambivalence. ${ }^{8}$ If the crime narratives had been told from another position, for example the position of fatherhood, we wonder if depicting violent or dangerous acts as "boyish pranks", diminishing the seriousness

8 There are a few exceptions, for example Sjöberg pointing out the dangerousness of having a fast sports car at young age and his ambivalence in relation to the violence against his former trainer. 
we see, would be plausible. All three authors have children, but hardly anything is said about them, nor of being a father. Not least in a Swedish context, where gender equality is highly valued and recognized, narratives of responsible, dedicated fatherhood could have been appreciated. The women in the authors' lives are given a little more space in the biographies than the children, but these too have a rather hidden role. Thus, hegemonic masculinity is not primarily constructed in relation to femininities, but in relation to other men and masculinities. The crime narratives are by and large used to subordinate other men. This is in line with earlier research showing that it is first and foremost other men that may pose a threat to masculinity (Messerschmidt 2004, 2018a; Pascoe 2011; Pettersson 2014).

We would like to emphasise that our study has presented little opportunity to describe any major range of nuances. We have chosen to focus on accounts of these men's own involvement in crime. These narratives construct masculinity in a relatively traditional way. The autobiographies do include more complex representations of masculinity than the crime accounts, which is interesting. As a resource for doing masculinity, crime appears to provide access to a limited repertoire of possibilities. By describing what was not written, but could have been, we have shown that several of the accounts might have been used to do other forms of masculinity. Looking to a question posed by Sandberg (2010:455), namely "which narratives are available?", we may say that crime, especially in the form of offences committed during youth, is also available to well-established men, who lack any form of criminal "label", as a means of doing masculinity, but also that narratives about crime are restrictively conditioned.

Masculinity must regularly be performed, it is not something that can be possessed once and for all. Doing gender is an ever-ongoing accomplishment and aging may pose a threat to masculinity. As an adult, mature man being violent and taking dangerous (sometimes even life threatening) risks is not in line with the social clock of the hegemonic masculinity script, but accounts of such behaviour (committed in their youth) are an excellent resource to (re)establish and (re)confirm masculinity. However, by no means all their accounts of crime are about crimes committed in the authors' youth. Several narratives depict crimes committed as socially well-established adults (for example Persson's drug offences, several of Sjöberg's speeding offences, Ibrahimović's theft at IKEA). This may be understood in the light of these men's working-class heritage. Jon's concept cowboy masculinity is by and large a working-class masculinity. The similarities between the autobiographies and Jon's hero story of cowboy masculinity are striking - for their fearlessness, potential for violence, intelligence, smartness, and resistance against oppressors and authorities.

What, then, may these depictions of former underdogs tell us about the context in which they are published and what significance can they be assumed to have? We argue, in line with Oksanen (2012) and Sandberg (2010), that the crime narratives that were chosen (and not chosen) for inclusion in the autobiographies says something about how working-class men can, and are allowed, to be depicted in our cultural context. The construction of cowboy masculinity confirms the middle- and upper-class view of the working class as "the dangerous class". The crime narratives 
in the autobiographies play upon this view and thus reproduce it. But does it matter more than on an analytical level? All three books have reached a large readership. Patrik Sjöberg's book sparked a great debate when released, and in 2018 he earned the title Honorary Doctor at Malmö University. Persson's book has also received a lot of attention. Ibrahimović's book has received the most attention. It has sold millions of copies, been translated into 30 languages and has been recognized for reaching young boys - a group that usually does not read books. Thus, the (dangerous) cowboy masculinity is presented as viable and even desirable for the readers. We do not say this was the authors' intention, but it is a consequence which illuminates the class-based narratives which are available to, for example, young boys who otherwise do not read books.

In conclusion we would like to point to the ambivalent signals and norms that boys and young men (and others!) face constantly in the form of media representations, and which are also reproduced in the autobiographies examined. On the one hand, crime is presented in the public debate as a great contemporary social problem, that society must take powerful measures to combat. On the other hand, not least in the field of popular culture, actions by men that (on the basis of a legalistic interpretation) constitute crimes may be portrayed as being both desirable and honourable. As long as crime accounts constitute a culturally accepted means of doing masculinity, we should not be surprised that crime statistics are dominated by young boys and men.

\section{Acknowledgements}

We would like to thank David Shannon for translating the article and the anonymous reviewers for their insightful suggestions.

\section{References}

Berggren, K. (2014) "Sticky masculinity post-structuralism, phenomenology and subjectivity in critical studies on men”, Men and Masculinities 17 (3): 231-252. https:// doi.org/10.1177/1097184x14539510

Bäcklin, E., C. Carlsson \& T. Pettersson (2013) "Maskuliniteter som livsloppsprocesser", 133-175, in Ungdomsstyrelsen, Unga och våld: En analys av maskulinitet och förebyggande verksambeter, Stockholm: Ungdomsstyrelsen.

Carlsson, C. (2013) "Masculinities, persistence, and desistance", Criminology 51 (3):661-693. https://doi.org/10.1111/1745-9125.12016

Connell, R.W. (1995) Masculinites. Berkeley: University of California Press.

Connell, R.W. \& J.W. Messerschmidt (2005) "Hegemonic masculinity: Rethinking the concept", Gender \& Society 19 (6):829-859. https://doi. org/10.1177/0891243205278639

Davies, P. (2011) Gender, crime and victimisation. London: Sage. http://dx.doi. org/10.4135/9781446251294 
Hammarén, N. (2008) Förorten i huvudet: Unga män om kön och sexualitet i det nya Sverige. Stockholm: Bokförlaget Atlas.

Ibrahimović, Z. (2013) I am Zlatan: My story on and off the field. London: Penguin Books.

Järvinen, M. (2004) "Life histories and the perspective of the present", Narrative Inquiry 14 (1): 45-68. https://doi.org/10.1075/ni.14.1.03jar

Jon, N. (2007) En skikkelig gutt. Arbeidet med å forme en passende maskulinitet på Foldin verneskole 1953-1970. Oslo: Unipub forlag.

Jon, N. (2014) "Transforming cowboy masculinity into appropriate masculinity", 19-38 in I. Lander, S. Ravn \& N. Jon (Eds.) Masculinities in the criminological field: Control, vulnerability and risk-taking. Farnham: Ashgate. https:// doi.org/10.4324/9781315594132-2

Kimmel, M.S. (1994) "Masculinity as homophobia: Fear, shame, and silence in the construction of gender identity", 81-93 in H. Brod \& M. Kaufmann (Eds.) Theorizing masculinities. Thousand Oaks: Sage. https://doi.org/10.4135/9781452243627.n7

Kimmel, M.S., \& M. Mahler (2003) "Adolescent masculinity, homophobia, and violence: Random school shootings, 1982-2001”, American Behavioral Scientist 46 (10):1439-1458. https://doi.org/10.1177/0002764203046010010

Kolnar, K. (2005) Mannedyret: Begjer i moderne film. Oslo: Spartacus.

Matza, D., \& G.M. Sykes (1961) "Juvenile delinquency and subterranean values", American Sociological Review 26 (5): 712-719. https://doi.org/10.2307/2090200

Merton, R.K. (1938) "Social structure and anomie", American Sociological Review 3 (5):672-682. https://doi.org/10.2307/2084686

Messerschmidt, J.W. (1993) Masculinities and crime: Critique and reconceptualization of theory. Lanham: Rowman \& Littlefield.

Messerschmidt, J.W. (1997) Crime as structured action: Gender, race, class, and crime in the making. Thousand Oaks: SAGE. https://doi.org/10.4135/9781452232294

Messerschmidt, J.W. (2004) Flesh and blood: Adolescent gender diversity and violence. Lanham: Rowman \& Littlefield.

Messerschmidt, J.W. (2018a) Masculinities and crime: A quarter century of theory and research. Lanham: Rowan \& Littlefield.

Messerschmidt, J.W. (2018b) Hegemonic Masculinity: Formulation, Reformulation, and Amplification. Lanham: Rowan \& Littlefield.

Messerschmidt, J.W. (2019) “The Salience of 'Hegemonic Masculinity”, Men and Masculinities 22 (1):85-91. https://doi.org/10.1177/1097184x18805555

Oksanen, A. (2012) "To hell and back: Excessive drug use, addiction, and the process of recovery in mainstream rock autobiographies", Substance Use \& Misuse 47 (2):143-154. https://doi.org/10.3109/10826084.2012.637441

Pascoe, C.J. (2012) Dude, you're a fag: Masculinity and sexuality in high school, with a new preface. Berkeley: University of California Press. https://doi. org/10.1525/9780520950696

Persson, L.G.W. (2011) Gustavs grabb: Berättelsen om min klassresa. Stockholm: Bonnier. 
Pettersson, T. (2012) Att balansera mellan kontroll och kontakt: Lokala polisers arbete med ungdomar. Lund: Studentlitteratur.

Pettersson, T. (2014) "Doing masculinity in youth institutions", 39-56 in I. Lander, S. Ravn \& N. Jon (Eds.) Masculinities in the criminological field: Control, vulnerability and risk-taking. Farnham: Ashgate. https://doi.org/10.4324/9781315594132-3

Sandberg, S. (2010) "What can 'lies' tell us about life? Notes towards a framework of narrative criminology", Journal of Criminal Justice Education 21 (4):447-465. https://doi.org/10.1080/10511253.2010.516564

Scott, M.B. \& S.M. Lyman (1968) "Accounts", American Sociological Review 33 (1):46-62. https://doi.org/10.2307/2092239

Segal, L. (2007) Slow motion: Changing masculinities, changing men. Basingstoke: Palgrave Macmillan. https://doi.org/10.1057/9780230582521

Sjöberg, P. \& M. Lutteman (2011) Det du inte såg. Stockholm: Norstedt.

Spector-Mersel, G. (2006) "Never-aging stories: Western hegemonic masculinity scripts", Journal of Gender Studies 15 (1):67-82. https://doi.org/10.1080/09589230500486934

Tham, H. (2018) Kriminalpolitik. Brott och straff i Sverige sedan 1965. Stockholm: Norstedts juridik.

Whitehead, S.M. (2002) Men and masculinities: Key themes and new directions. Cambridge: Polity Press.

\section{Authors}

Monica Skrinjar (Ph.Lic. in Criminology) is a $\mathrm{PhD}$ student at the Department of Criminology, Stockholm University. Her research has focused on drug use, drug policy, and gender and crime. While writing this article, she worked as a lecturer at the Department of Social Work and Criminology at the University of Gävle.

Tove Pettersson is a professor of Criminology and works at the Department of Criminology, Stockholm University. Her research interests include gender and crime, discrimination in the judiciary, institutional care of young persons, and police research. She has authored several books and participated in several anthologies.

\section{Corresponding author}

Tove Pettersson

Kriminologiska institutionen

Stockholms universitet, 10691 Stockholm.

tove.pettersson@criminology.su.se 